${ }^{1}$ Setor de Endocrinologia Experimental, Departamento de Farmacologia, Universidade Federal de São Paulo - Escola Paulista de Medicina (UnifespEPM), São Paulo, SP, Brasil

"These authors contributed equally to this work
Correspondence to: Maria Christina W. Avellar Setor de Endocrinologia Experimental, Departamento de Farmacologia, Unifesp-EPM Rua Três de Maio, 100 - Infar 04044-020 - São Paulo, SP, Brasil avellar@unifesp.br

Received on Nov/13/2009 Accepted on Nov/14/2009

\section{Androgens and the male reproductive tract: an overview of classical roles and current perspectives}

\author{
Androgênios e o trato reprodutor masculino: \\ ações clássicas e perspectivas atuais
}

Marilia T. C. C. Patrão ${ }^{1 \#, ~ E r i c k ~ J . ~ R . ~ S i l v a ~}{ }^{1 \#, ~ M a r i a ~ C h r i s t i n a ~ W . ~ A v e l l a r ~}{ }^{1}$

\begin{abstract}
Androgens are steroid hormones that play key roles in the development and maintenance of male phenotype and reproductive function. These hormones also affect the function of several non-reproductive organs, such as bone and skeletal muscle. Endogenous androgens exert most of their effects by genomic mechanisms, which involve hormone binding to the androgen receptor $(A R)$, a ligand-activated transcription factor, resulting in the modulation of gene expression. AR-induced non-genomic mechanisms have also been reported. A large number of steroidal and non-steroidal AR-ligands have been developed for therapeutic use, including the treatment of male hypogonadism (AR agonists) and prostate diseases (AR antagonists), among other pathological conditions. Here, the $A R$ gene and protein structure, mechanism of action and $A R$ gene homologous regulation were reviewed. The AR expression pattern, its in vivo regulation and physiological relevance in the developing and adult testis and epididymis, which are sites of sperm production and maturation, respectively, were also presented. Arq Bras Endocrinol Metab. 2009;53(8):934-45
\end{abstract}

Keywords

Androgen receptor; male reproductive tract; testis; epididymis

\section{RESUMO}

Os androgênios são hormônios esteroides com papel fundamental no desenvolvimento e na manutenção do fenótipo masculino e da função reprodutiva. Esses hormônios também afetam a função de diversos tecidos não reprodutivos, como, por exemplo, o ósseo e musculoesquelético. Os androgênios endógenos exercem a maioria de suas funções por mecanismo genômico, que envolve a ligação do hormônio ao receptor de androgênio (RA), um fator de transcrição ativado por ligante, o que resulta no controle da expressão gênica. Mecanismos não genômicos também têm sido associados aos efeitos induzidos pelo RA. Um grande número de ligantes do RA, esteroidais e não esteroidais, tem sido desenvolvido para o uso terapêutico, incluindo o tratamento do hipogonadismo masculino (agonistas do RA) e de doenças da próstata (antagonistas do RA), entre outras condições patológicas. Neste trabalho, foram discutidas as características estruturais básicas do RA (gene e proteína), os mecanismos de ação desse receptor, bem como aspectos relacionados à sua regulação homóloga. $O$ padrão de expressão do RA, sua regulação in vivo e relevância fisiológica durante o desenvolvimento e a vida adulta na função do testículo e epidídimo, tecidos responsáveis pela produção e maturação de espermatozoides, respectivamente, também foram discutidos. Arq Bras Endocrinol Metab. 2009;53(8):934-45

Descritores

Receptor de androgênio; trato reprodutor masculino; testículo; epidídimo

\section{INTRODUCTION}

$\Delta$ ndrogens are steroid hormones primarily involved

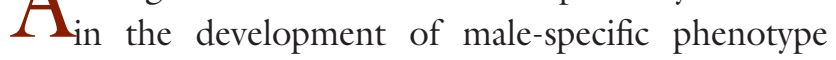

during embryogenesis, in the establishment of sexual maturation at puberty, and in the maintenance of the male reproductive function, spermatogenesis and sexual 
behavior during adult life. They also affect a wide variety of functions in non-reproductive tissues, such as bone and skeletal muscle, on both male and female (for review, see 1).

Endogenous androgens, mainly testosterone and its active metabolite dihydrotestosterone (DHT), exert most of their effects by binding to the androgen receptor (AR), a ligand-activated transcription factor, which results in the control of gene transcription by the interaction of AR with coregulators and specific DNA sequences of androgen-responsive genes of the target cells. Recently, a number of rapid, non-genomic effects have also been associated with AR activation by androgens, with physiological relevance to be still determined. Due to the involvement of androgens in a large number of pathological processes, several synthetic steroidal and non-steroidal AR ligands have been developed and are widely used in clinical applications, including the treatment of male hypogonadism (AR agonists) and prostate diseases (AR antagonists), among others.

In this review, the basic aspects of the AR gene and protein structure, the molecular mechanisms of androgen action and the regulation of $A R$ gene by androgens are presented. Aspects of the pattern of AR expression, its in vivo regulation during development and adulthood and its physiological relevance in the testis and the epididymis, which are sites of sperm production and maturation, respectively, are also briefly reviewed.

\section{ANDROGEN RECEPTOR GENE AND PROTEIN STRUCTURE}

The AR belongs to the nuclear hormone receptor superfamily of ligand-activated transcription factors that also includes receptors for other mammalian steroid hormones, such as glucocorticoid receptor (GR), mineralocorticoid receptor (MR), progesterone receptor (PR) and estrogen receptors (ER $\square$ and ER $\square$ ).

The human $A R$ gene is located on $\mathrm{X}$ chromosome at position Xq11-q12 (2), spanning over 90-kilobase $(\mathrm{kb})$ pairs that comprise eight exons, a large 5'-untranslated region (5'-UTR, 1.1-kb in size) and a very large 3'-untranslated region (3'-UTR, 6.8-kb in size) $(3,4)$. Highly conserved human $A R$ orthologs have been described in different species, including mouse and rat (57). All $A R$ exons contribute to a transcript that encodes a modular protein of 919 amino acids with an apparent molecular mass of $110 \mathrm{kDa}(6)$. Differential splicing in the 3'-UTR are known to produce two major $A R$
mRNA species (11- and 8.5-kb, respectively) in different cell lines and tissues $(3,6,8)$, with unknown physiological function. At least three major transcription initiation sites, in an 18-base pair region located over 1-kilobase upstream the ATG translation initiation codon, have been identified in the human $A R$ gene (8), while only two of these sites are observed in the mouse and rat $(5,9)$. Studies in different species, including human (10), mouse (5), rat (9) and hamster (11) have revealed that the promoter region of $A R$ gene lacks typical TATA and CAAT sequence motifs in the 5'-UTR, two common motifs that are recognized by components of the transcriptional machinery. It contains, however, a CG-rich region that is an important cis-acting element for $A R$ gene transcription and a putative site that binds the constitutive active transcription factor Spl. Multiple consensus sequences that recognize different transcription factors are also present in $A R$ promoter region of different species, including AR itself, GR, ER, activating protein-1 (AP-1), cAMP responsive binding element (CREB), among others $(9,11,12)$.

Like other members of its family, the structure of $\mathrm{AR}$ is organized into functional domains, consisting of a N-terminal domain (NTD), encoded by exon $\mathrm{l}$; a DNA-binding domain (DBD), encoded by exons 2 and 3 ; and a C-terminal ligand-binding domain (LBD), which is encoded by the last five exons (4). There is also a small hinge region between DBD and LBD. Whereas the DBD and LBD of the AR are highly conserved among species, the NTD display the most sequence variability, which is important for differences in the homeostatic control and complexity of AR signaling (13). The AR NTD is relatively long, representing almost half of the receptor coding sequence; it contains the major transactivation function domain of the AR, termed activation function $\mathrm{l}(\mathrm{AFl})$, which is responsible for almost all AR transcriptional activity (14). Mutagenesis and deletion studies have indicated that, in a construct corresponding to a truncated AR lacking the LBD, the AFl becomes constitutively transcriptional active (14). Additionally, AFl mediates interactions with transcriptional coregulators and members of the basal transcriptional machinery (for review, see 15). The AR NTD also contains motifs that interact with LBD after agonist binding, resulting in an amino-/carboxi-terminal intra- and/or intermolecular interaction, named N/C interaction, which may be critical for the transcriptional activation of some AR target genes (for review, see 16). 
The cystein-rich DBD is the most conserved region within the nuclear receptor family, with identical amino acid sequence when AR DBD from human, rat and mouse are compared $(5,6)$. This domain contains two zinc finger motifs and a C-terminal extension. The first zinc finger mediates specific DNA recognition, whereas the second is involved in AR homodimerization and DNA/receptor complex stabilization (17). The C-terminal region of DBD and the hinge region contain ligand-dependent bipartite nuclear localization signals (NLS), indicating the role of these regions on AR translocation to the cell nucleus (18).

The LBD mediates high affinity interactions between $\mathrm{AR}$ and its steroidal and non-steroidal ligands. It is also important for $\mathrm{AR}$ interactions with chaperones (19). The three-dimensional structure of this domain was described early this decade (20). Similar to other steroid hormone receptors, the AR LBD consists of 12 -helices that form a ligand-binding pocket. Upon agonist binding, there is a conformational change in $\mathrm{LBD}$, resulting in the stabilization of helix 12 and the formation of a functional activation function 2 (AF2) on the surface of this domain. AF2 plays a pivotal role on intra- and intermolecular N/C interactions, which may further stabilize AR-bound androgen complex and play a role on receptor dimerization (16,21). The LBD is also involved in the recruitment of coregulators during transcriptional activation. Nevertheless, N/C interactions usually impair the access of coregulators to $\mathrm{AF} 2$, which may explain why AF1 is the major transactivation region of the AR, a phenomenon not observed with ER and GR, for example (16). Although AR AF2 ligand-dependent transactivation activity is weak when compared with similar domains from other steroid hormone receptors, its importance for AR function was demonstrated by discrete reductions on its transcriptional activity in response to ligand after mutations or deletion of AF2 region (16).

\section{MOLECULAR MECHANISMS OF ANDROGEN ACTION}

The classic genomic actions of androgens are based on the AR-mediated control of gene transcription. This mechanism usually requires at least 30 to 40 minutes to alter gene expression and hours to produce significant levels of newly expressed proteins. In the target cell, testosterone diffuses through the plasma membrane and interacts with AR trapped in the cytoplasm by a mul- tiprotein complex with heat shock proteins (HSP) and immunophilin chaperones, including HSP90, HSP70, HSP56 and p23 (19). After ligand binding, AR undergoes a conformational change, allowing its release from the multiprotein complex. This dissociation unmasks AR NLS and dimerization motifs, allowing its increased phosphorylation, nuclear translocation and homodimerization. In the nucleus, activated AR-ligand homodimer complex binds to specific recognition DNA sequences, the androgen response elements (AREs), localized in the promoter regions of androgen-regulated genes. The presence of functional AREs in enhancer intronic regions of AR-regulated genes has been also reported (22).

Studies with recombinant human AR demonstrated that homodimerization is critical for DNA binding (23). The consensus ARE sequence has been identified as a partial palindromic 15-base pair element comprised of two imperfect 6-base pair indirect repeats with a 3-base pair space (5'-GG(A/T)ACANNNTGTTCT-3') (for review, see 24). After binding to ARE, AR-ligand homodimer complex can either directly interacts with components of the general transcriptional complex or recruits other components, such as transcriptional factors or coregulator proteins that act as a functional link between the transcriptional machinery and the AR-mediated transcriptional activity (for review, see 19). AR coregulators can be defined as proteins that are recruited by the AR and either enhance (coactivators) or reduce (corepressors) its transcriptional activity, but lack intrinsic DNA binding capacity and do not change basal transcription rate in the absence of AR. Coregulators modulate AR-mediated transactivation at the target gene promoter region by several mechanisms, including direct enhancement of AR to control gene transcription rate, modulation of DNA binding, chromatin remodeling, and recruitment of other factors associated with RNA polymerase II. According to the Nuclear Receptor Signaling Atlas (NURSA) database (http://www.nursa.org), over 250 nuclear receptor coregulator proteins have been identified. Many of them interact with AR and regulate its activity, including steroid receptor coactivator l (SCR-1) (25), AR-associated protein 70 (ARA 70) (26), melanoma antigen gene product (MAGE-11) (27), among others (see Heemers and Tindall (19), for a comprehensive review). It is also known that AR further regulates gene expression by physical or functional interactions with transcription factors that bind to specific consensus se- 
quences, such as AP-1 (28), SRY and DAXI (29). Androgens may also indirectly influence the expression of genes that do not necessarily contain canonical AREs in their promoter regions, involving modulation in the expression or activity of secondary transcription factors, the production of growth factors acting in an autocrine or paracrine fashion or changes in the expression of other hormones. The development of selective androgen receptor modulators (SARMs) that potentially regulate aspects of tissue-specific AR activation, such as ligand-induced receptor conformational changes, protein-protein interactions, and protein-DNA interactions, has been highly explored due to their potential therapeutic applications as target for male contraception and their use in different clinical conditions, such as prostate cancer, benign prostatic hyperplasia, osteoporosis, among others (for review, see 30 ).

There are growing evidences indicating that androgens are also able to trigger cellular processes through rapid, non-genomic mechanisms in different isolated cells and tissues, including testis and prostate (for review, see 31). These non-genomic actions usually occur in seconds or minutes, not long enough to allow gene transcription and translation. It is often dependent on plasma membrane-associated signaling pathways that will lead to the activation of cytoplasmic second messengers, a mechanism that is not sensitive to transcriptional or translational inhibitors. The most common non-genomic actions of androgens involve either rapid activation of kinase-associated intracellular signaling, including mitogen-activated protein kinase (MAPK) and protein kinase A (PKA) pathways, or the modulation of intracellular calcium levels. The molecular mechanisms underlying these actions and their physiological relevance remain largely unknown.

It has been also suggested that non-genomic mechanisms may be involved on the effects of androgens in the male reproductive tract. In fact, a rapid increase in the intracellular calcium concentration was observed when primary rat Sertoli cells and human androgen-dependent (LNCaP) and androgen-independent (PC3) human prostate cancer cells were exposed to testosterone, DHT and R1881 - a synthetic AR agonist (32). Similar results were obtained when these cells were stimulated with a membrane-impermeable androgen analogue (testosterone-conjugated to bovine serum albumin, T-BSA) (32). Furthermore, testosterone was able to induce a rapid increase on the concentration of the transcriptional factor CREB in rat primary Sertoli cell culture, via MAPK pathways, an effect impaired either by the knockdown of $A r$ gene expression by siRNA or by incubation of the cells with an AR antagonist (flutamide), providing evidence that classical $A R$ is required to initiate this non-genomic actions of testosterone in Sertoli cells (33). However, not all androgen-mediated non-genomic effects are blocked by the classical AR antagonists (for review, see 31). It is also important to cite that there are evidences that isolated rat Sertoli cells and LNCaP cells contain a population of plasma membrane associated AR, which can be transiently increased in response to testosterone stimulation (32). Thus, whether non-genomic actions in the male reproductive tract are mediated by classical AR, by a membrane-bound AR or by another membrane-associated signaling pathway and its potential actions in other reproductive tissues still require further investigation.

\section{MECHANISMS OF HOMOLOGOUS REGULATION OF ANDROGEN RECEPTOR}

The regulation of $\mathrm{AR}$ expression by androgens is an important mechanism to self-regulate cell or tissue androgen responsiveness. This homologous regulation is a complex time-, cell- and tissue-dependent event that involves the combination of transcriptional and posttranscriptional mechanisms. In fact, androgens can autoregulate the expression of $A R$ transcript in both negative and positive directions, according to the celltype analyzed. Northern blot studies conducted with LNCaP cells indicated that testosterone and DHT, as well as synthetic androgen agonists (R1881 and mibolerone), down-regulate $A R$ mRNA levels in these cells in a concentration- and time-dependent pattern $(8,34$, 35 ), an effect caused by a predominant suppression of $A R$ transcription associated with a paradoxical increase in AR mRNA half-life (from 5.5 hours in the absence of androgen to over 12 hours in the presence of $10 \mathrm{nM}$ DHT) $(8,35)$. A similar reduction of the $A R$ mRNA levels after androgen treatment was observed in human breast cancer cell lines T47D and MDA453 $(34,35)-$ in this case, as a consequence of post-transcriptional reduction on $A R$ mRNA half-life (35), suggesting the existence of cell-type specific mechanisms involved in the regulation of $A R$ mRNA expression. In a marked contrast, DHT increased $A R$ mRNA steady-state levels in human osteoblastic cell lines (SaOS-2 and U2OS) that constitutively express AR, an effect induced by an increase in $A R$ promoter activity, which depends on $\mathrm{AR}$ 
transactivation mechanisms (36). Interestingly, studies conducted with monkey kidney COS-1 cells (37) and androgen independent cell lines PC3 and DU145 (38), all transiently transfected with human $A R$ cDNA and stimulated with R1881, have indicated the presence of regulatory regions within the $A R$ coding sequence that are important in $A R$ gene homologous regulation. In fact, studies using PC3 cells transiently transfected with human $A R$ cDNA have confirmed the presence of functional AREs in exons 4 and 5 of $A R$ gene (39).

Androgens can also up regulate the AR levels by promoting protein stabilization. In fact, degradation rate studies conducted in monkey kidney COS-1 cells transfected with $A R$ cDNA demonstrated that, in the absence of androgen, the AR half-life is approximately $\mathrm{l}$ to 1.5 hour at $37^{\circ} \mathrm{C}(40,41)$. After androgen exposure, the AR half-life significantly increases in a concentrationdependent manner (10 to 11 hours in the presence of $10 \mathrm{nM} \mathrm{DHT}$ and over 14 hours in the presence of 100 nM DHT) (40,41). This effect also directly depends on the androgen dissociation rates, since testosterone was less effective at increasing AR half-life than similar concentrations of DHT and R1881, which are agonists with higher affinity to AR (41). Higher degradation rates of an AR with a natural mutation in the LBD (valine-889 conversion to methionine), a receptor presenting an increased androgen dissociation rate when compared to AR-wild type in the presence of similar concentration of androgens, further indicate the importance of androgen binding for AR stabilization (41). Besides, agonistinduced AR stabilization is highly androgen-specific, since treatment with non-androgenic steroids failed to increase AR half-life (40). Analysis of AR deletion mutants and AR/GR chimeras clearly demonstrate that AR NTD and LBD, but not DBD, play an important role on receptor stabilization after androgen binding (4l). Indeed, N/C interaction induced by ligand binding is associated with AR stabilization (16).

Although androgens are recognized as the main modulators of the development and maintenance of the male phenotype and reproductive function, the exact molecular mechanisms underlying in vivo homologous regulation of $\mathrm{AR}$ and its mechanism of action are still poorly understood in reproductive tissues, since most studies concerning these aspects are mainly based on in vitro cell lines $(8,34,35,38)$. In this aspect, a better comprehension of the differential regulatory aspects of in vivo AR expression and its regulation is useful to further understand the exact physiological roles of andro- gens, as well as other steroid and non-steroid AR ligan$\mathrm{ds}$, in the male reproductive tract and in the acquisition of a fertile ejaculate. Next, special focus will be given on the aspects regarding the pattern of AR expression and regulation by androgens, as well as its physiological relevance in the testis and epididymis during development and adult life.

\section{EXPRESSION AND PHYSIOLOGICAL ROLES OF ANDROGEN RECEPTOR IN THE TESTIS AND EPIDIDYMIS}

\section{Fetal testis and Wolffian ducts}

Androgens are responsible for the development of the male phenotype during embryogenesis. They are involved in testicular development, stabilization of the Wolffian duct and its differentiation into epididymis, vas deferens, seminal vesicle and ejaculatory duct, as well as in the differentiation of the prostate and external genitalia (for review, see 42,43 ). Testosterone is produced by fetal Leydig cells at the eighth week of gestation in humans and at embryonic days 13 and 15 in mice and rats, respectively (43). In male rat fetuses (embryonic days 15 to 19$), \mathrm{AR}$ is expressed earlier and more prominently in the interstitial cells surrounding testicular cords, including Leydig cells, in response to testosterone secretion $(44,45)$. On the other hand, AR-positive Sertoli cells are not detected until postnatal day 5 in rats and postnatal days 4-9 in mice and their number, as well as AR immunostaining intensity, increases over time $(44,45)$. Thus, testosterone up regulates the expression of $\mathrm{AR}$ in the Leydig cells, but is not likely to be directly involved with Sertoli cell functions during fetal life $(44,45)$.

Testosterone produced by embryonic Leydig cells reaches the Wolffian duct in two ways: (A) by the circulation (endocrine interaction) and (B) by the testicular fluid (lumicrine interaction). Lumicrine interaction involves testosterone reaching the Wolffian duct by the luminal compartment and is thought to be the main mechanism involved in Wolffian duct stabilization in the male fetus (for review, see 43). It is suggested that testosterone reaches the Wolffian duct bound to androgen binding protein $(\mathrm{ABP})$, indicating that this protein may be important to the maintenance of high androgen levels in the proximal region of the duct when compared to the remaining tissue (46). In the rat, the Wolffian duct first expresses AR in the mesenchymal cells at embryonic day 14-15 and subsequently in the epithelial 
cells $(44,47)$. Testosterone reaching the Wolffian duct by the luminal compartment up regulates AR levels and induces proliferation of the epithelial cells through mesenchymal-epithelial cell interactions involving paracrine factors (48). At this stage, growth factors and components of the extracellular matrix are proposed to be important mediators from the mesenchyme to the epithelium (49). Recently, it has been suggested that circulating androgens are also important to induce Wolffian duct stabilization and subsequent formation of epididymides, as well as prostatic bud formation, virilization of the urogenital sinus and prostatic development (50).

It is known that steroid hormones and growth factors are involved in the complex regulation of cell proliferation and differentiation during pre- and postnatal development of the male reproductive tract (for review, see 43). Microarray analysis of the genes differentially expressed in the Wolffian ducts of male rat fetuses from mothers treated with the weak anti-androgen linurion, from days 12 to 21 of pregnancy, has demonstrated significant changes in mRNA expression of insulin-like growth factor 1 (IGF-1), bone morphogenetic protein (BMP), fibroblast growth factor (FGF) and epidermal growth factor (EGF) signaling pathways, consistent with a disruption of paracrine interactions between mesenchymal and epithelial cells in the testosterone-mediated development of the Wolffian duct. A significant decrease in $A r$ transcript levels in the Wolffian duct at embryonic day 21 is also observed in this experimental model, confirming that $A r$ mRNA expression is induced by androgens in this structure (51).

\section{Adult testis and epididymis}

In the adult male mouse and rat testes, AR is detected predominantly in the nuclear region of Sertoli, peritubular myoid, Leydig and perivascular smooth muscle cells (52-54), presenting a stage-specific pattern of immunostaining $(53,54)$. The presence of AR in the germ cells and spermatozoa, however, is controversial and seems to depend on the species analyzed (for review, see 55). The fact that Sertoli cells AR conditional knockout mice are infertile, whereas germ cell conditional AR knockout mice are fertile, suggests that the role of AR on spermatogenesis is indirect and occurs via Sertoli cells (55). On the other hand, immunofluorescence, Western blot and functional assays have revealed that human ejaculated sperm expresses a functional AR in its head region, since changes in phosphoinositide-3 kinase/protein kinase B (PI3K/AKT) signaling pathway by a non-genomic me- chanism were observed after incubation of these cells with DHT (56). However, the role of androgens in the maturing sperm is still unknown, since no information is available about the expression and function of $A R$ in these cells during their transport throughout the epididymis, an organ from the male reproductive tract involved in the maturation, transport, protection and storage of spermatozoa prior to ejaculation (for review, see 57).

The epididymis is constituted by a single, highly convoluted tubule, which connects the efferent ductules to the vas deferens. Based on its morphological and histological characteristics, this tissue can be divided into different regions (initial segment, caput, corpus and cauda) depending on the species analyzed. The epithelium of the epididymis contains different cell types: principal, basal, clear, narrow and halo cells (for review, see 57). Lumicrine interaction between androgens and $\mathrm{AR}$ involves transport of testosterone bound to $\mathrm{ABP}$ from the testis to the proximal region of the epididymis. Testosterone/ABP complexes are then taken up to the cytoplasm of the epithelial cells, where $5 \square$-reductase enzyme converts this hormone into DHT, the main androgen regulating epididymal function (58). In the adult rat, ABP is localized in granules in the apical cytoplasm of the epithelial cells from initial segment and proximal caput, but not from distal caput, corpus and cauda epididymis (59), indicating its importance on the maintenance of high androgen levels in the proximal epididymis when compared to the remaining tissue (59). In fact, it is known that androgen concentrations are higher in the caput than in cauda epididymis (60) and that during postnatal development, which occurs from day 0 to day 44 after birth in rats, histological differentiation of the caput precedes that of the cauda (for review, see 57). Besides, the abundance of AR-positive cells in the epididymis increases in a time-dependent manner during postnatal development, which further confirms the involvement of this receptor in the normal epididymal development (44). In the adult rat and human epididymis, AR is present predominantly in the nuclear region of epithelial, interstitial and smooth muscle cells lining epididymal tubules and blood vessels (52, $61)$ and also in the cytoplasm of epithelial cells $(54,61)$. The AR distribution pattern in the different regions of the adult rat epididymis can be seen in figure 1 .

Surgical castration has been a useful tool to understand the roles of luminal and circulating androgens on AR function (58). This procedure induces a wave of apoptotic cell death in the epididymis, which occurs 

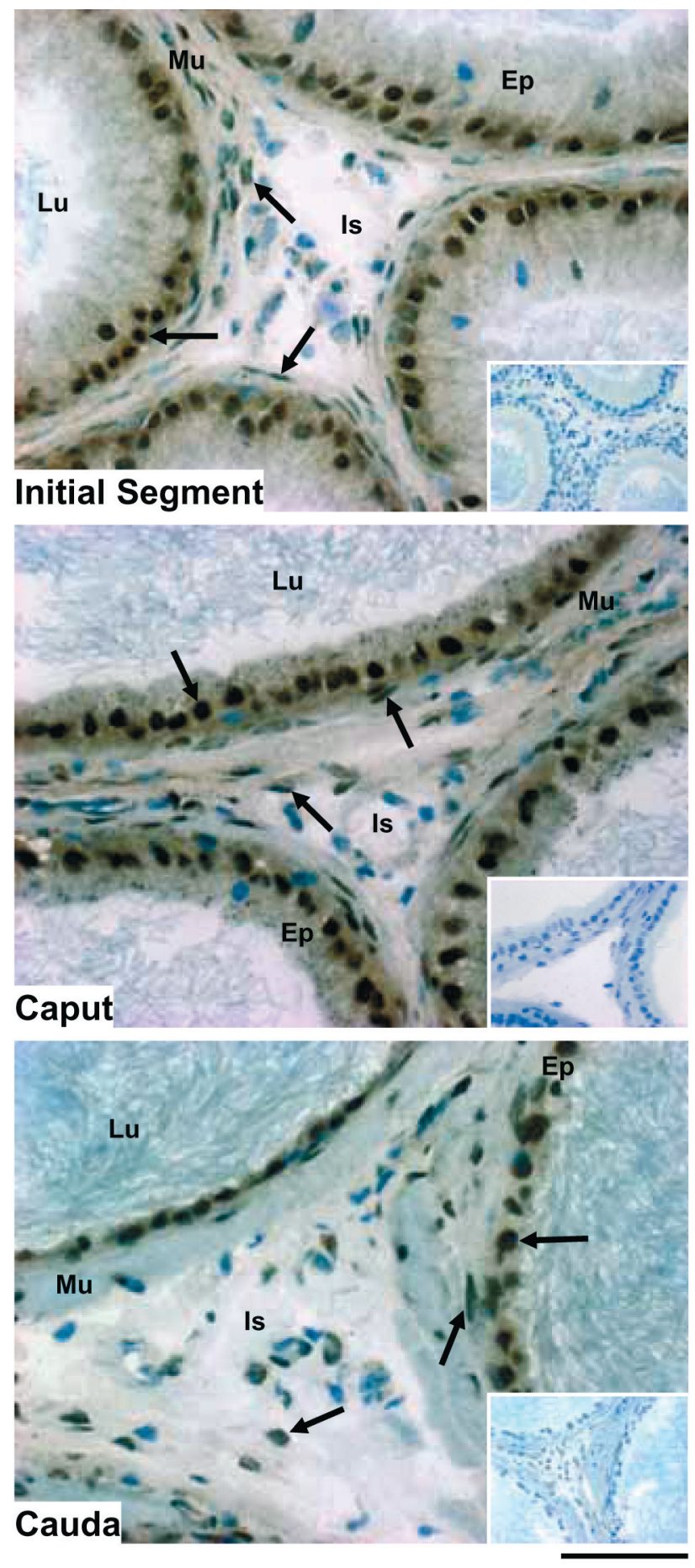

Figure 1. Immunolocalization of AR in the initial segment, caput and cauda epididymis from adult Wistar rats (90 days of age). Immunohistochemistry was conducted in our laboratory with cryosections $(8 \mu \mathrm{m})$, as described by Queiróz and cols. (74), with an affinity purified rabbit polyclonal antibody raised against a peptide mapping at the N-terminus of $A R$ of human origin, which also recognizes rat $A R$ (1:500, Sc-816, Santa Cruz Biotechnology). Negative controls were performed with primary antibody previously incubated with its respective blocking peptide from Santa Cruz (inserts). Sections were counterstained with methylene blue. The different epididymal compartments lumen (Lu), epithelium (Ep), interstitium (Is) and smooth muscle layer (Mu) are indicated. Results are representative of experiments performed with tissues from four rats. Arrow: AR-positive nuclear staining. A faint diffuse and punctate immunostaining can also be observed in the cytoplasm of epithelial cells in all epididymal regions analyzed. Scale bar: $50 \mu \mathrm{m}$. progressively from the proximal to the distal region of this tissue (62). After surgical castration, a decrease in epididymal weight, luminal diameter and epithelial cell height, as well as a relative increase in the interstitial compartment are observed (for review, see 57). The secretory and absorptive function of epithelial cells becomes compromised, which is accompanied by the loss of apical microvilli from their surface, lysosome accumulation, vacuolization, disappearance of vesicles from the cell apex, and increased endocytosis (for review, see 57). Testosterone replacement to castrated rats restores most of the histological features of the epithelium, except in the initial segment, due to its high dependence on other nonhormonal testicular factors $(63,64)$. In fact, testosterone replacement to castrated rats triggers cell proliferation in a segment-specific and time-dependent manner, with corpus and cauda being the most affected regions (64).

As a result of the differential regulation by androgens and other hormonal and non-hormonal factors, epididymal gene expression is segmentally regulated (51). In fact, the control of gene transcription by androgens varies along the epididymis and is differentially affected with progression of surgical castration (65). Microarray analysis of 474 genes was used to evaluate gene expression changes over the first seven days postsurgical castration in the initial segment, caput, corpus, and cauda epididymis from adult rats. Several genes encoding proteins involved in cell viability and metabolism, as well as sperm maturation, were shown to be androgen-regulated (65). Microarray analysis of 31,000 genes indicated that, of the 1,059 genes that were affected by surgical castration after seven days, DHT treatment for seven consecutive days was capable of restoring over $75 \%$ of the gene levels toward the control, indicating that testosterone and DHT may differentially regulate the relative levels of such gene transcripts along rat epididymis (58). Data from our laboratory further confirm that differential regulation by androgens can also occur in the expression of genes encoding G-protein coupled receptors along rat epididymis, such as $\square_{1}$-adrenoceptor (66) and acetylcholine muscarinic receptor (67), which are receptors involved in the autonomic regulation of epididymal function (for review, see 68$)$.

\section{HOMOLOGOUS REGULATION OF ANDROGEN RECEPTOR IN ADULT TESTIS AND EPIDIDYMIS}

In the testis from adult males, androgen withdrawal induces AR cellular redistribution and up regulates AR 
levels. Adult rats treated with ethane dimethane sulphonate (EDS), to eliminate the Leydig cells, presented low binding of ${ }^{3} \mathrm{H}-\mathrm{R} 1881$ to AR in the nuclear fraction of testicular cells when compared to controls (69). The total testicular AR was close to control levels, indicating that in the absence of androgens, AR is redistributed to the cytoplasm of such cells (69). On the other hand, immunohistochemical studies have revealed that treatment of adult male mice with the GnRH antagonist azaline $\mathrm{B}$, used to suppress $\mathrm{LH}$ and testosterone production, induces down-regulation of the receptor in the Leydig, peritubular and Sertoli cells (54).

Regarding the homologous regulation of $\mathrm{AR}$ expression in the epididymis, radioligand binding studies demonstrated that bilateral efferent ductules ligation (EDL) for seven days does not affect the relative num- ber of AR binding sites in the caput epididymis, whereas bilateral surgical castration up to 20 days results in a decrease on AR binding sites, which points out for the importance of circulating rather than luminal androgens on the regulation of AR expression (70). The Ar mRNA levels in the initial segment from adult rats submitted to EDL for 24 hours did not differ from sham-operated rats, confirming the low dependence of AR expression by luminal androgens (71). Immunohistochemical studies demonstrated that bilateral surgical castration down regulates AR expression in the goat epididymis, an effect reversed by testosterone replacement. In this experimental model, neither unilateral ligation of the rete testis nor unilateral surgical castration had any effect on AR expression (72). As shown in figure 2, our laboratory has evidences of an up regulation of $\mathrm{Ar}$
A

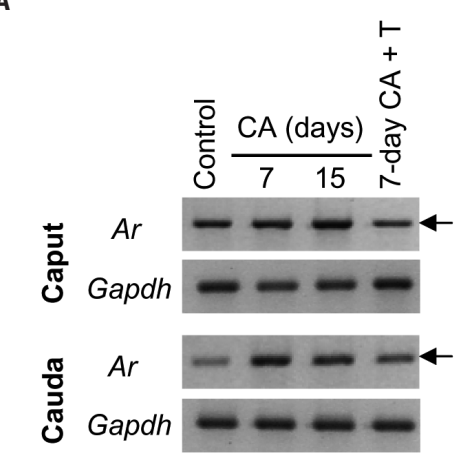

C

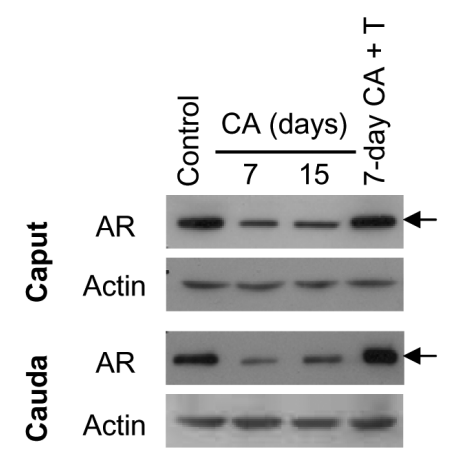

B

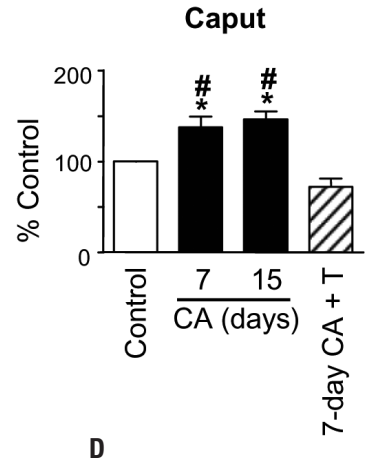

Caput

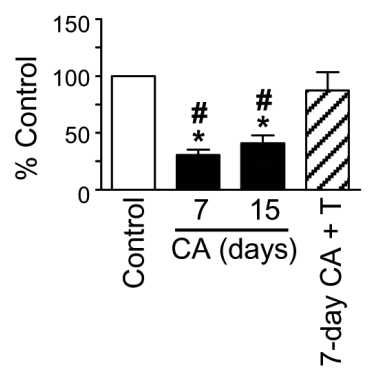

Cauda

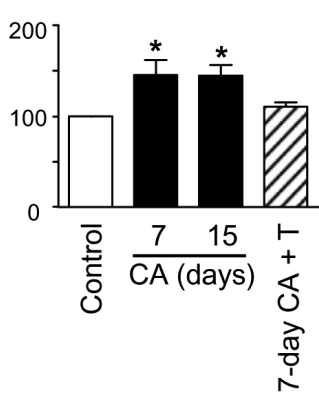

Cauda

Figure 2. Effects of the manipulation of androgen plasma levels on AR expression in epididymis from adult Wistar rats (90 days of age). Caput (including initial segment) and cauda epididymis were obtained from control, surgical castrated (CA, 7 and 15 days) and 7-day CA rats treated with testosterone propionate (7-day CA + T, $10 \mathrm{mg} / \mathrm{kg}$, S.C., daily injections for six days). (A) Detection of ArmRNA by RT-PCR in caput and cauda epididymis from the different experimental groups, as indicated. The 600 base pair band correspondent to Ar transcript is indicated (right arrow). (B) Densitometric analysis of the RT-PCR results. Each sample was normalized to its respective internal standard (Gapdh). (C) AR detection by Western blot analysis using caput and cauda epididymis total protein extracts from the different experimental groups, as indicated. Experiments were performed with an anti-AR antibody (1:600, Sc-816, Santa Cruz Biotechnology). Negative controls were performed with primary antibody previously incubated with its blocking peptide (data not shown). The $110 \mathrm{kDa}$ band correspondent to the full length AR is indicated (right arrow). (D) Densitometric analysis of the Western blot results. Each sample was normalized to its respective internal standard (actin). Results are representative of experiments performed with tissues from four to five rats. Each bar and vertical line represent the normalized data expressed as percentage of control group (mean \pm SEM). RT-PCR and Western blot studies were performed as described by Rodrigues and cols. (75). ${ }^{*} p<0.05$ when compared with control group; \# $p<0.05$ when compared with 7 -day CA + T group. 

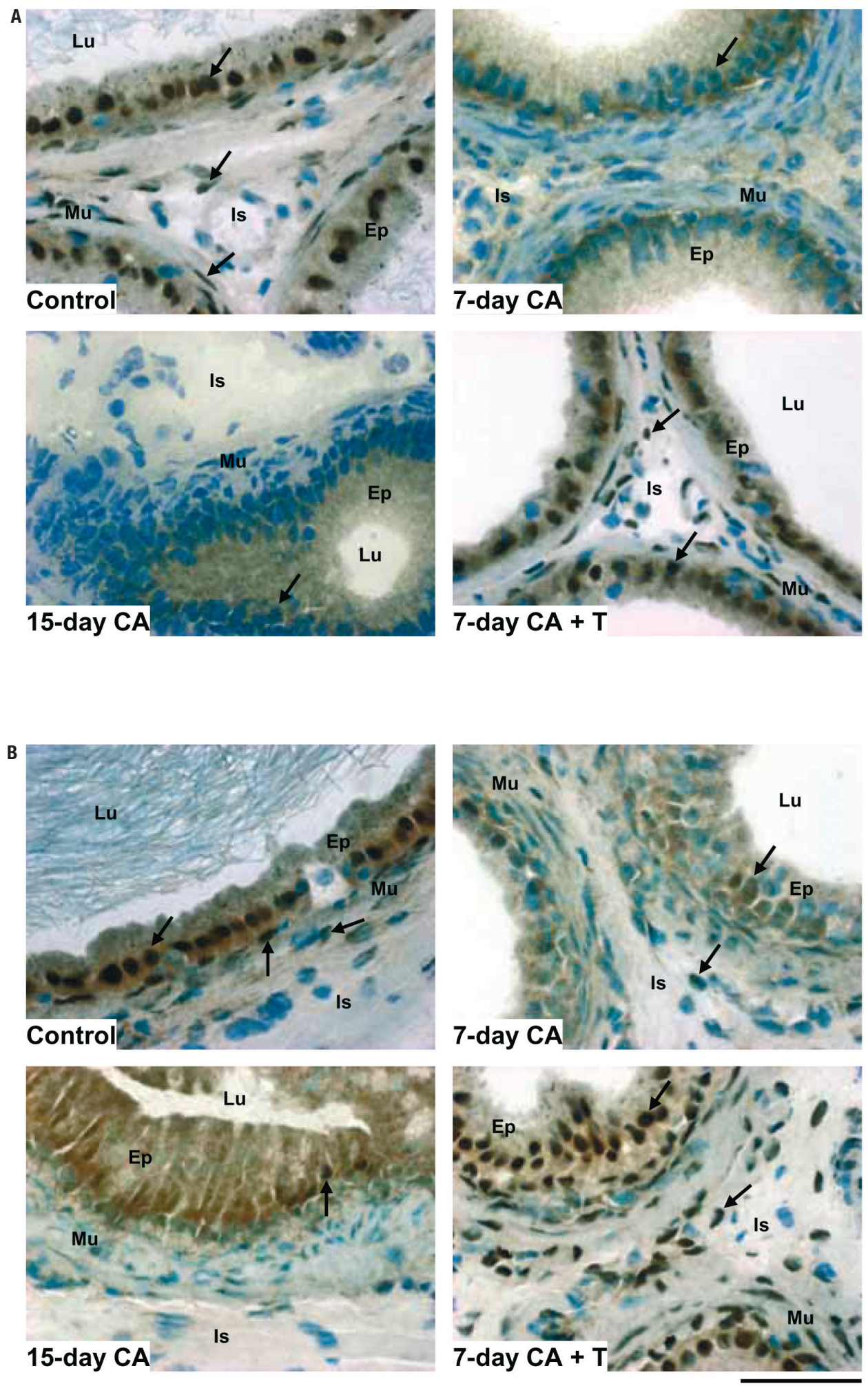

Figure 3. Effects of the manipulation of androgen plasma levels on AR cellular distribution in epididymis from adult Wistar rats (90 days of age). Immunolocalization of AR using cryosections $(8 \mu \mathrm{m})$ from caput (A) and cauda epididymis (B) from control, surgical castrated (CA, 7 and 15 days) and 7-day CA rats treated with testosterone propionate (7-day $\mathrm{CA}+\mathrm{T}, 10 \mathrm{mg} / \mathrm{kg}$, S.c., daily injections for six days) is shown. Experiments were performed as described by Queiróz and cols. (74), using an anti-AR antibody (1:500, Sc-816, Santa Cruz Biotechnology). Negative controls were performed with primary antibody previously incubated with its respective blocking peptide from Santa Cruz (data not shown). Sections were counterstained with methylene blue. The different epididymal compartments lumen (Lu), epithelium (Ep), interstitium (Is) and smooth muscle layer (Mu) are indicated. Results are representative of experiments performed with tissues from four to five rats. Arrow: AR-positive nuclear staining. Scale bar: $50 \mu \mathrm{m}$. 
mRNA levels with a concomitant down regulation of AR protein levels, that occur in both caput and cauda epididymis of adult rats submitted to bilateral surgical castration for 7- and 15-days, suggesting the existence of differential mechanisms of AR regulation at mRNA and protein levels by endogenous androgens in the rat epididymis, as also described in studies performed with cell lines $(8,34,35,40,41)$. Our immunohistochemistry, using epididymal cryosections from the same animals, indicated a significant reduction on AR-positive nuclear staining in epithelial cells from caput and cauda epididymis after castration (Figure 3). Remarkably, no AR-positive immunostaining was observed in interstitial and smooth muscle cells of caput epididymis from castrated rats, further indicating the existence of different regulatory mechanisms of $\mathrm{AR}$ expression between the epididymal cells (Figure 3). In fact, immunohistochemical studies performed with epididymis from chemically castrated rats treated with azaline $\mathrm{B}$ also demonstrate a time-dependent reduction on AR-positive nuclear staining, observed earlier in interstitial than in epithelial epididymal cells (54). Testosterone replacement (10 $\mathrm{mg} / \mathrm{kg}$, s.c., daily injections during six days) for 7-day castrated rats was able to restore AR expression, at both mRNA and protein levels in caput and cauda epididymis, reinforcing the importance of circulating androgens on such regulation (Figures 2 and 3). Similar results were obtained when immunohistochemical studies were performed with the epididymis from rats treated with the $5 \square$-reductase inhibitor finasteride that inhibits the conversion of testosterone into DHT (73).

\section{CONCLUDING REMARKS}

New information has been obtained in the last decade in relation to the mechanism of action of androgens, which is known to involve genomic, and also non-genomic signaling pathways induced by AR. However, further investigation is still required to fully understand how these events collectively contribute to AR physiological function in the male reproductive tract, especially to testis and epididymis, tissues highly involved in the achievement of male fertility. It is hoped that information on selective AR modulators (SARMs) and $\mathrm{AR}$ coregulator proteins, that potentially regulate aspects of tissue-specific AR activation, will serve as tools to be used not only for more efficient pharmacological modulation of the AR in pathological processes, such as certain conditions of male hypogonadism, diseases of the prostate and osteoporosis, as well as for the development of therapies for male contraception and treatment of male infertility.

Acknowledgments: the authors acknowledge the financial support given by Fundação de Amparo à Pesquisa do Estado de São Paulo (Fapesp), Conselho Nacional de Desenvolvimento Científico e Tecnológico (CNPq) and Coordenação de Aperfeiçoamento de Pessoal de Nível Superior (Capes).

Disclosure: no potential conflict of interest relevant to this article was reported.

\section{REFERENCES}

1. Matsumoto T, Shiina H, Kawano H, Sato T, Kato S. Androgen receptor functions in male and female physiology. J Steroid Biochem Mol Biol. 2008;109(3-5):236-41.

2. Lubahn D, Joseph D, Sullivan P, Willard H, French F, Wilson E. Cloning of human androgen receptor complementary DNA and Iocalization to the X chromosome. Science. 1988;240(4850):327-30.

3. Faber PW, van Rooij HC, van der Korput HA, Baarends WM, Brinkmann AO, Grootegoed JA, et al. Characterization of the human androgen receptor transcription unit. J Biol Chem. 1991;266(17):10743-9.

4. Kuiper GGJM, Faber PW, van Rooij HCJ, van der Korput JAGM, Ris-Stalpers C, Klaassen $P$, et al. Structural organization of the human androgen receptor gene. J Mol Endocrinol. 1989;2(3):R1-4.

5. Faber PW, King A, van Rooij HC, Brinkmann AO, de Both NJ, Trapman J.The mouse androgen receptor. Functional analysis of the protein and characterization of the gene. Biochem J. 1991;278 (Pt 1):269-78.

6. Lubahn DB, Joseph DR, Sar M, Tan J-A, Higgs HN, Larson RE, et al. The human androgen receptor: complementary deoxyribonucleic acid cloning, sequence analysis and gene expression in prostate. Mol Endocrinol. 1988;2(12):1265-75.

7. Tan J-A, Joseph DR, Quarmby VE, Lubahn DB, Sar M, French FS, et al. The rat androgen receptor: primary structure, autoregulation of its messenger ribonucleic acid, and immunocytochemical localization of the receptor protein. Mol Endocrinol. 1988;2(12):1276-85.

8. Wolf D, Herzinger T, Hermeking H, Blaschke D, Horz W. Transcriptional and posttranscriptional regulation of human androgen receptor expression by androgen. Mol Endocrinol. 1993;7(7):924-36.

9. Baarends WM, Themmen AP, Blok LJ, Mackenbach P, Brinkmann $A O$, Meijer $D$, et al. The rat androgen receptor gene promoter. Mol Cell Endocrinol. 1990;74(1):75-84.

10. Tilley WD, Marcelli M, McPhaul MJ. Expression of the human androgen receptor gene utilizes a common promoter in diverse human tissues and cell lines. J Biol Chem. 1990;265(23):13776-81.

11. Varriale B, Esposito T. The hamster androgen receptor promoter: A molecular analysis. J Steroid Biochem Mol Biol. 2005;94(13):103-10.

12. Mizokami A, Yeh S, Chang C. Identification of $3^{\prime}, 5^{\prime}$-cyclic adenosine monophosphate response element and other cis-acting elements in the human androgen receptor gene promoter. Mol Endocrinol. 1994;8(1):77-88.

13. Li J, Al-Azzawi F. Mechanism of androgen receptor action. Maturitas. 2009;63(2):142-8.

14. Simental JA, Sar M, Lane MV, French FS, Wilson EM. Transcriptional activation and nuclear targeting signals of the human androgen receptor. J Biol Chem. 1991;266(1):510-8. 
15. Kumar R, Litwack $G$. Structural and functional relationships of the steroid hormone receptors' $\mathrm{N}$-terminal transactivation domain. Steroids. 2009;74(12):877-83.

16. He B, Wilson EM. The $\mathrm{NH}(2)$-terminal and carboxyl-terminal interaction in the human androgen receptor. Mol Genet Metab. 2002;75(4):293-8.

17. Gelmann EP. Molecular biology of the androgen receptor. J Clin Oncol. 2002;20(13):3001-15.

18. Haelens A, Tanner T, Denayer S, Callewaert L, Claessens F. The hinge region regulates DNA binding, nuclear translocation, and transactivation of the androgen receptor. Cancer Res. 2007;67(9):4514-23.

19. Heemers HV, Tindall DJ. Androgen receptor (AR) coregulators: a diversity of functions converging on and regulating the AR transcriptional complex. Endocr Rev. 2007;28(7):778-808.

20. Sack JS, Kish KF, Wang C, Attar RM, Kiefer SE, An Y, et al. Crystallographic structures of the ligand-binding domains of the androgen receptor and its T877A mutant complexed with the natural agonist dihydrotestosterone. Proc Natl Acad Sci USA. 2001;98(9):4904-9.

21. Farla P, Hersmus R, Geverts B, Mari PO, Nigg AL, Dubbink HJ, et al. The androgen receptor ligand-binding domain stabilizes DNA binding in living cells. J Struct Biol. 2004;147(1):50-61.

22. Avellar MCW, Gregory CW, Power SGA, French FS. Androgen-dependent protein interactions within an intron 1 regulatory region of the 20-kDa protein gene. J Biol Chem. 1997;272(28):17623-31.

23. Wong Cl, Zhou ZX, Sar M, Wilson EM. Steroid requirement for androgen receptor dimerization and DNA binding. Modulation by intramolecular interactions between the NH2-terminal and steroid-binding domains. J Biol Chem. 1993;268(25):19004-12.

24. Gobinet J, Poujol N, Sultan C. Molecular action of androgens. Mol Cell Endocrinol. 2002;198(1-2):15-24.

25. Bevan CL, Hoare S, Claessens F, Heery DM, Parker MG. The AF1 and AF2 domains of the androgen receptor interact with distinct regions of SRC1. Mol Cell Biol. 1999;19(12):8383-92.

26. Zhou Z-X, He B, Hall SH, Wilson EM, French FS. Domain interactions between coregulator ARA70 and the androgen receptor (AR). Mol Endocrinol. 2002;16(2):287-300.

27. Bai $\mathrm{S}, \mathrm{He} B$, Wilson EM. Melanoma Antigen Gene Protein MAGE11 regulates androgen receptor function by modulating the interdomain interaction. Mol Cell Biol. 2005;25(4):1238-57.

28. Kallio P, Poukka H, Moilanen A, Janne O, Palvimo J. Androgen receptor-mediated transcriptional regulation in the absence of direct interaction with a specific DNA element. Mol Endocrinol. 1995;9(8):1017-28.

29. Yuan X, Lu ML, Li T, Balk SP. SRY interacts with and negatively regulates androgen receptor transcriptional activity. J Biol Chem. 2001;276(49):46647-54.

30. Gao W, Bohl CE, Dalton JT. Chemistry and structural biology of androgen receptor. Chem Rev. 2005;105(9):3352-70.

31. Foradori CD, Weiser MJ, Handa RJ. Non-genomic actions of androgens. Front Neuroendocrinol. 2008;29(2):169-81.

32. Lyng FM, Jones GR, Rommerts FFG. Rapid androgen actions on calcium signaling in rat Sertoli cells and two human prostatic cell lines: similar biphasic responses between 1 picomolar and 100 nanomolar concentrations. Biol Reprod. 2000;63(3):736-47.

33. Fix C, Jordan C, Cano P, Walker WH. Testosterone activates mitogen-activated protein kinase and the cAMP response element binding protein transcription factor in Sertoli cells. Proc Natl Acad Sci USA. 2004;101(30):10919-24.

34. Krongrad A, Wilson CM, Wilson JD, Allman DR, McPhaul MJ. Androgen increases androgen receptor protein while decreasing receptor mRNA in LNCaP cells. Mol Cell Endocrinol. 1991;76(13):79-88.
35. Yeap BB, Krueger RG, Leedman PJ. Differential posttranscriptional regulation of androgen receptor gene expression by androgen in prostate and breast cancer cells. Endocrinology. 1999;140(7):3282-91.

36. Wiren KM, Zhang X, Chang C, Keenan E, Orwoll ES. Transcriptional up-regulation of the human androgen receptor by androgen in bone cells. Endocrinology. 1997;138(6):2291-300.

37. Burnstein KL, Maiorino CA, Dai JL, Cameron DJ. Androgen and glucocorticoid regulation of androgen receptor cDNA expression. Mol Cell Endocrinol. 1995;115(2):177-86.

38. Le Dai J, Maiorino CA, Gkonos PJ, Burnstein KL. Androgenic upregulation of androgen receptor cDNA expression in androgenindependent prostate cancer cells. Steroids. 1996;61(9):531-9.

39. Grad JM, Le Dai J, Wu S, Burnstein KL. Multiple Androgen Response Elements and a Myc Consensus Site in the Androgen Receptor (AR) Coding Region Are Involved in Androgen-Mediated Up-Regulation of AR Messenger RNA. Mol Endocrinol. 1999;13(11):1896-911.

40. Kemppainen JA, Lane MV, Sar M, Wilson EM. Androgen receptor phosphorylation, turnover, nuclear transport, and transcriptional activation. Specificity for steroids and antihormones. J Biol Chem. 1992;267(2):968-74.

41. Zhou Z, Lane M, Kemppainen J, French F, Wilson E. Specificity of ligand-dependent androgen receptor stabilization: receptor domain interactions influence ligand dissociation and receptor stability. Mol Endocrinol. 1995;9(2):208-18.

42. Cool J, Capel B. Mixed Signals: Development of the Testis. Semin Reprod Med. 2009;27(01):005-13.

43. Hannema SE, Hughes IA. Regulation of Wolffian duct development. Horm Res. 2007;67(3):142-51.

44. You L, Sar M. Androgen receptor expression in the testes and epididymides of prenatal and postnatal Sprague-Dawley rats. Endocrine. 1998;9(3):253-61.

45. Rey RA, Musse M, Venara M, Chemes HE. Ontogeny of the androgen receptor expression in the fetal and postnatal testis: Its relevance on Sertoli cell maturation and the onset of adult spermatogenesis. Microscopy Research and Technique. 2009;72(11):787-95.

46. Becchis $M$, Sullivan PM, Ordronneau $P$, Petrusz $P$, Joseph DR. Distribution of immunoreactive androgen-binding protein/sex hormone-binding globulin in tissues of the fetal rat. Steroids. 1996;61(7):392-400.

47. Bentvelsen FM, Brinkmann $\mathrm{AO}$, van der Schoot $\mathrm{P}$, van der Linden JE, van der Kwast TH, Boersma WJ, et al. Developmental pattern and regulation by androgens of androgen receptor expression in the urogenital tract of the rat. Mol Cell Endocrinol. 1995;113(2):245-53.

48. Cunha GR, Alarid ET, Turner T, Donjacour AA, Boutin EL, Foster BA. Normal and abnormal development of the male urogenital tract. Role of androgens, mesenchymal-epithelial interactions, and growth factors. J Androl. 1992;13(6):465-75.

49. Turner KJ, Mclntyre BS, Phillips SL, Barlow NJ, Bowman CJ, Foster PMD. Altered gene expression during rat wolffian duct development in response to in utero exposure to the antiandrogen linuron. Toxicol Sci. 2003;74(1):114-28.

50. Renfree MB, Fenelon J, Wijiyanti G, Wilson JD, Shaw G. Wolffian duct differentiation by physiological concentrations of androgen delivered systemically. Dev Biol. 2009;334(2):429-36.

51. TurnerT, Bomgardner D, Jacobs J, Nguyen Q. Association of segmentation of the epididymal interstitium with segmented tubule function in rats and mice. Reproduction. 2003;125(6):871-8.

52. Sar M, Lubahn DB, French FS, Wilson EM. Immunohistochemical localization of the androgen receptor in rat and human tissues. Endocrinology. 1990;127(6):3180-6.

53. Zhou Q, Nie R, Prins GS, Saunders PTK, Katzenellenbogen BS, Hess RA. Localization of androgen and estrogen receptors in adult male mouse reproductive tract. J Androl. 2002;23(6):870-81.

54. Zhu L-J, Hardy MP, Inigo IV, Huhtaniemi I, Bardin CW, Moo-Young AJ. Effects of androgen on androgen receptor expression in rat 
testicular and epididymal cells: a quantitative immunohistochemical study. Biol Reprod. 2000;63(2):368-76.

55. Wang R-S, Yeh S, Tzeng C-R, Chang C. Androgen receptor roles in spermatogenesis and fertility: lessons from testicular cell-specific androgen receptor knockout mice. Endocr Rev. 2009;30(2):119-32.

56. Aquila S, Middea E, Catalano S, Marsico S, Lanzino M, Casaburi I, et al. Human sperm express a functional androgen receptor: effects on PI3K/AKT pathway. Hum Reprod. 2007;22(10):2594-605.

57. Robaire B, Hermo L. Efferent ducts, epididymis and vas deferens: structure and functions and their regulation. In: Knobil E, Neil JD, editors. The Physiology of Reproduction. New York: Raven Express; 1988. p. 999-1080.

58. Robaire B, Seenundun S, Hamzeh M, Lamour SA. Androgenic regulation of novel genes in the epididymis. Asian J Androl. 2007;9(4):545-53.

59. Pelliniemi LJ, Dym M, Gunsalus GL, Musto NA, Bardin CW, Fawcett DW. Immunocytochemical localization of androgen-binding protein in the male rat reproductive tract. Endocrinology. $1981 ; 108(3): 925-31$.

60. TurnerTT, Ewing LL, Jones CE, Howards SS, Zegeye B. Androgens in male rat reproductive tract fluids: hypophysectomy and steroid replacement. Am J Physiol Endocrinol Metab. 1985;248(3):E274-80.

61. Ungefroren $\mathrm{H}$, Ivell $\mathrm{R}$, Ergun $\mathrm{S}$. Region-specific expression of the androgen receptor in the human epididymis. Mol Hum Reprod. 1997;3(11):933-40.

62. Fan $\mathrm{X}$, Robaire B. Orchidectomy induces a wave of apoptotic cell death in the epididymis. Endocrinology. 1998;139(4):2128-36.

63. Fawcett DW, Hoffer AP. Failure of exogenous androgen to prevent regression of the initial segments of the rat epididymis after efferent duct ligation or orchidectomy. Biol Reprod. 1979;20(2):162-81.

64. Hamzeh M, Robaire B. Effect of testosterone on epithelial cell proliferation in the regressed rat epididymis. J Androl. 2009;30(2):200-12

65. Ezer N, Robaire B. Gene expression is differentially regulated in the epididymis after orchidectomy. Endocrinology. 2003;144(3):975-88.
66. Queiróz DB, Mendes FR, Porto CS, Avellar MC. Alpha1-adrenoceptor subtypes in rat epididymis and the effects of sexual maturation. Biol Reprod. 2002;66(2):508-15.

67. Maróstica E, Avellar MC, Porto CS. Effects of testosterone on muscarinic acetylcholine receptors in the rat epididymis. Life Sci. 2005;77(6):656-69.

68. Avellar MC, Lazari MF, Porto CS. Expression and function of Gprotein-coupled receptors in the male reproductive tract. An Acad Bras Cienc. 2009;81(3):321-44.

69. Blok LJ, Bartlett JM, Bolt-De Vries J, Themmen AP, Brinkmann AO, Weinbauer GF, et al. Effect of testosterone deprivation on expression of the androgen receptor in rat prostate, epididymis and testis. Int J Androl. 1992;15(2):182-98.

70. Pujol A, Bayard F. Androgen receptors in the rat epididymis and their hormonal control. J Reprod Fertil. 1979;56(1):217-22.

71. Yang L, Fox SA, Kirby JL, Troan BV, Hinton BT. Putative regulation of expression of members of the Ets variant 4 transcription factor family and their downstream targets in the rat epididymis. Biol Reprod. 2006;74(4):714-20.

72. Goyal HO, Bartol FF, Wiley AA, Khalil MK, Williams CS, Vig MM. Regulation of androgen and estrogen receptors in male excurrent ducts of the goat: An immunohistochemical study. Anat Rec. 1998;250(2):164-71.

73. Trybek G, Kolasa A, Marchlewicz M, Wenda-Rozewicka L, Wiszniewska B. Immunolocalization of androgen receptor in the epididymis of rats with dihydrotestosterone deficiency. Reprod Biol. 2005;5(3):291-301.

74. Queiróz DB, Silva AM, Gutierrez-Ospina G, Porto CS, Grossman $G$, Petrusz $P$, et al. Cells positive for microtubule-associated protein 1B (MAP 1B) are present along rat and human efferent ductules and epididymis. Cell Tissue Res. 2006;325(1):125-33.

75. Rodrigues A, Queiróz DBC, Honda L, Silva EJR, Hall SH, Avellar MCW. Activation of toll-like receptor 4 (TLR4) by in vivo and in vitro exposure of rat epididymis to lipopolysaccharide from Escherichia coli. Biol Reprod. 2008;79(6):1135-47. 